\title{
Local Government Financing Instruments, the Case of Albania
}

\author{
Msc. Ermira Korra \\ Assistant Lectuer at University of Elbasan Albania, Economic Faculty, Finance - Account Department \\ Email address: ermirakorra@yahoo.com \\ Dr. Eliona Gremi \\ Lectuer at University of Elbasan Albania, Economic Faculty, Finance - Account Department \\ Email address: eliona.gremi@uniel.edu.al \\ Msc. Faik Gjolena \\ Elbasan, Albania \\ Email address: faik.gjolena@gmail.com
}

Doi:10.5901/ajis.2016.v5n3s1p387

\begin{abstract}
In the terms of decentralization and local autonomy, increase of financial capacity, is the result of more use of fiscal and financial instruments, as well as increasing the effectiveness work of the local government. They are facing a series of complex issues related to the functions they have to carry and their financial capacities against these needs. Local Government Units in Albania have few funds to fill the needs for financing great projects mainly infrastructure, so in this paper we aim to analyze the financing instruments of local government. Borrowing from financial institutions and second level banks is the main financial instrument for Local Government to financing their great investment for the community. This is a new financing instrument for LGUs in Albania that is considered as a strong financial lever to enable the financing of their budgets and great projects capital investment. Another instrument are guidelines constructed in similar models and experiences of countries in political and economic tradition with that of Albania, the issue of bonds of $L G$ / municipal bonds which are regulated by laws. Programs of international agencies to support lending to the local government is also another a significant financing instrument for LGUs in Albania to fulfilled their needs.
\end{abstract}

Keywords: Financing instruments, local government, bond, municipal bonds.

\section{Introduction}

In most countries in Europe and Albania one of the major topics in many discussions in economics and finance is the rising stock of public debt, the volatility of economic growth, reforms to counter the global financial crisis, the new challenges of local government with regard to their financial capabilities, and the actions taken by the central government under the decentralization process.

In many discussions taken place, the instrument of local government financed through loans from the financial system/banking has it difficult to attract the attention of, and find appropriate implementation among stakeholders and regulatory authorities. In Albania the local borrowing law, which was approved on February 2008, and the law of October 2009 on the municipal obligations have a little awareness in the banking market, meanwhile the local units see their importance as the key to implementing strategic investment.

Compliance with the legal framework and bank rating are necessary, however not the only conditions that a local unit should fulfill in order to borrow. Successful financial management requires a proactive approach, where local policymakers will have to conduct cost-benefit analysis for each project and respectively adjust their investment policy with their current debt capacity.

In general, under the framework of managing public debts, countries of Central and Eastern Europe consider the legal and institutional restrictions on local borrowing as part of the restrictions on total public debt. In these countries, central government is considered as the main responsible actor in the management process of the total public debt, whereas local government and its performance are seen as highly dependent on central financial and fiscal policies. 


\section{For an Efficient Borrowing of Local Government in Albania}

Before making any consideration on borrowing instruments at the hands of the local government in Albania and on improving the efficiency of their use, one is required to start presenting the latest territorial and administrative reform, implemented in the country. A panorama of the territorial and administrative landscape will be of help to the reader, by going through the borrowing mechanism of the local government and getting the whole picture. Following the introductory part, this article intends to address and discuss on how local government can make use of the obtained financing, in an efficient way.

The Government of Albania undertook an important territorial and administrative reform, which reshaped the panorama of local government. Basically, as from the last local elections, the Republic of Albania has been divided in 61 (large) municipalities and 12 districts. The rationale behind the reform it is believed to be the creating of large municipalities (or super municipalities likewise Tirana), with efficient, although large, local administration, which will be able to offer more qualitative services. The above reform obviously was driven and accompanied by the relevant amendments the legislation, regulating local government. The territorial and administrative reform in Albania initiate with the adoption of the law No.115/2014: "On the Administrative and Territorial Division of Local Government Units in the Republic of Albania", as amended. The law was approved by the Albanian Parliament, on 31 July, 2014 and entered into force on 16 September, 2014, following its publication in the Official Gazette. Further changes to the legislation regulating the local government units were adopted by the Albanian Parliament, including herein the law No. 30/2015, which amends the law No. 8652/2000: "On organization and functioning of the local government" as amended.

Notwithstanding the need for improvement and approximation with the European Union legislation, the current legal framework provides adequate regulation for the creation of a local government borrowing system and improvement of the efficiency in using such borrowings for the development of the local infrastructure and services.

Concluding here the panorama of essential changes in the administrative and territorial landscape of the country and returning our focus to the issues of local borrowing, it is worth mentioning that, the main piece of legislation regulating local government borrowing is the law No. 9869, dated 04.02.2008: "On the borrowing of the local government" and the law No. 10158, dated 15.10.2009: "On bonds of joint stock companies and local government". Based on the provisions of the Law 9869/2008, local governments units can go out in the market and seek short and long term loans, either for investment purposes (long term), or to bridge liquidity shortages (short term). Local government can reach out capital markets, or financial institutions, to obtain the line of credit and this means in local or foreign currency at fixed/variable interest rate. As for the modus operandi to reach out and obtain the loan, both short and long term borrowing are somehow subject to the veto of the Ministry of Finance.

In the case of the short term loan, the local government unit is bound to obtain the 'negative response' by the Ministry of Finance that the state budget will not cover liquidity needs. With regard to long term loan, the Minister of Finance will have the final say on the approval, in case the loan will be obtained in the international markets, or is needed to service the debt of previous loan, or the local government unit is a distressed one that has demonstrated financial difficulties in the past five years. In such case, the approval of the Minister of Finance is decisive. On cases other than the above-mentioned ones the approval of the Minister of Finance is limited to the procedural compliance on the loan authorization and verification the loan limits, as prescribed by the provisions of the above-mentioned law on local government borrowing. The approval by the Ministry of Finance should not be considered, in any case, a guarantee of the Republic of Albania, backing the borrowing of the local government.

\section{Local Government Financing Instruments in Albania}

\subsection{Bank loans}

Loans are a financing instrument usually used today in capital investment projects by LGUs worldwide. Loans are granted by commercial or savings banks. The terms of a bank loan vary depending on the financial capacities of LGUs that requires financing by the macroeconomic environment of the administrative unit as well as the willingness of the bank to finance the LGUs concerned.

As we mentioned above administrative procedures that allow obtaining loans from banks and other financial institutions are less complicated and easier than those for bond issuance. On the other side, large projects of investments are more difficult to finance through loans from a single bank or even from a group of banks compared with financing through bonds. For more bonds have longer term than loans, because some of the institutional investors (such 
as pension funds, insurance companies) by buying these bonds they depend their expectations on longer-term sources of income than those of banks.

In some cases, banks may decide to renew a current loan on the maturity date, by pushing its maturity. However, the restructuring of a long-term financing through short-term loans, which are renewed at maturity, exposes the local government unit concerned with refinancing risk - eg. lender may oppose the renewal of the loan in discussion. This may lead to problems of liquidity or inability to comply debt obligations for the local unit and projects partially completed. The cost of the loan consists of the interest rate and other commissions that the bank uses to administer the loan (notary costs, administrative, cost of closing the loan before the deadline and penalties for disrespecting of contractual obligations, etc.). Bank determines interest rates of loans based on market interest rates, of loans maturity, collaterals for her, credibility and financial capacity of the borrower. Interest rates can be fixed or variable. Variable interest rates based on reference rates (eg EURBOR) plus a fixed margin.

Bank loan has its benefits and disadvantages against the other instruments of external funding unit:

The strengths:

a. is an easier funding source to acquired in financial market;

b. the procedure of bank borrowing is much easier than the issuing of municipal bonds (for this reason it is a most interesting instrument for small and medium local units);

c. the loans analysis is directly realized by banks that are offered to finance LGUs;

d. usually it is not required for LGU credit rating from banks;

e. conditions and deadlines of the loan are negotiated between the bank and the LGUs, but in the end are determined by the borrower's financial condition and the market segment where it operates bank lending.

Weaknesses:

a. Interest rates tend to be higher against the other funding instruments

b. the collateral terms are more stringent than for other instruments

c. it is not adequate for the financing of large investment projects which require long-term loan

\subsection{Programs of international agencies to support lending local units}

Generally, in countries that want to promote lending to local government are created special Development Funds for this purpose. This has been the experience of countries in the region. These development funds are functioning as lending institutions for local government units. International development banks (like WB, KFW, EBRD, etc.) use these funds as a way leading loans to LGUs. Funding LGs through these programs occurs in a way directly or indirectly (sub-loans), with the mediation of loan that channeled through the local banks (within the country) in countries where there such development programs.

The deadlines and conditions of these loans tend to be more elastic than those of usual banks. Their objective is to support long-term financing needs of the LGs and not to create profit. The loan maturity is usually associated with the longevity of the asset that is financed. Another characteristic of these loans is the grace period they apply, which aims to push the cost of debt in future periods.

Even the rate of interest of these loans is lower than what "usually" is used by commercial banks. Mainly are used fixed interest rates that are based for reference on the interest rate at which the Central Government borrows. But also it is important to mention that such interest rates under market interest rate bring the risk to lay out of function lending market of local government.

\subsection{Local Government bonds / municipal bonds}

Local government units are entitled to issue bonds in domestic or international market through municipal bonds, in execution with the law 10158/2009, as another way of local government financing through borrowing. As in case of loans, local government may issue short and long term bonds that mandatorily should be backed a relevant borrowing plan and audited by an external licensed audit entity. The bond for its holder is a debt title that brings interest issued by an institution / organization to borrow money. It is a debt agreement between the borrower (issuer) and the lender (investor).

The issuer usually pays for funds that borrows a constant periodic rate of interest (known as coupon). Principal payment is made only with a single installment payment at maturity or in several installments throughout the life of the bond, (eg. linear or progressive amortization increasing or decreasing).

Usually municipal bonds are traded by investment banks or commercial banks. The legal framework in our country 
adjusts this debt instrument by law no. 10158, dated 15.10.2009 "On bonds of joint stock companies and local government", a law that has not materialized even a single case of issuing bonds for local government (municipal bonds).

The types and series of municipal bonds are:

General obligation bonds are issued to finance the investment projects of interest for all the community (like, to improve public safety, roads, parks and recreational areas and public buildings). For this reason for the repayment of this debt (bond) should contribute all taxpayers of the local unit (individuals or businesses). Consequently the repayment of this bond is ensured by total income of the LGUs. Croatia is a country that has widely used general obligation bond since 2004 in some of its municipalities. All these bonds are secured only by the LGU that has issued them by putting the total income of their budgets as guarantee.

Income Bonds are also known as bonds with "limited liability" because they base their debt service only on certain income designated to LGU (like cleaning fees; the rents of public buildings, etc.). The revenue through which obligation of respective bond is paid mainly derived from the project which is financed by these bonds. Income bonds are not paid by taxes of the local government unit, but by specific income deriving the following of investment made by the respective loan.

Euro obligations are international bonds issued in a different currency from the country that issues the bond, not only in Euro. Euro obligations are marketable and securities transferable. Euro obligations usually issued through a public offering and are quoted on the Stock Exchange of Securities. Albania is still far using of this kind instrument for local governments considering that the central government itself / Ministry of Finance issued the first Euro obligation not earlier than 2010. However this is a borrowing instrument also applied in the region.

\subsection{Public - private partnerships (PPPs)}

Public - private partnerships (PPPs) are another form of cooperation that would improve the creditworthiness and satisfy the needs of local government units, for investments with financial exposures stretched over a long term of period. This specific form of cooperation, between public and private bodies, regulated by the Law 125/2013, dated 25.04.2013: "On concessions and public private partnership", as amended, provides two favorable conditions to the local government units that aim to carry out investment, using this form of cooperation. In one hand the risk and costs of immediate investment is transferred to the private partner and, on the other hand, cost repayment is stretched over the years of the contract entered with a private partner, thus avoiding the creation of short term repayable obligations in the finances of the local government.

Despite the need for improvement and approximation with the European Union legislation, the current legal framework provides adequate regulation for the creation of a local government borrowing system and improvement of the efficiency in using such borrowings for the development of the local infrastructure and services.

Therefore, the reform initiated with the reshape of territorial and administrative division should continue with the financial discipline and efficient administration of taxes, collected by local government, aiming at increasing the creditworthiness of local government units in the eyes of lenders, and to benefit maximally from the opportunities provided by legal framework, on borrowing options and their efficient use.

\section{New Territorial Reform, the Opprtunities for Local Borrowing}

The main objective of the 2015 territorial reform aims at avoiding the inefficiencies of public services at local level, which was mainly caused by extensive territorial fragmentation and a large number of local government units (LGUs). Although the new territorial division is based on the principle of "functional areas", any solid analysis on how such division could produce territorial development through private entrepreneurship is hardly found, throughout the paperwork produced in the frame of this reform. This is so, in a time when the relative weight of local government to the Gross Domestic Product (GDP) and to budget expenditures (BE) remains relatively lower levels. Despite the increase in revenues, generated from its own resources and exploitation of new resources, the local fiscal authority remains weak and its dependence on national resources, very high. Thus, the new municipalities will continue to experience major lack of financial resources for investment, especially those which require huge capital funding.

Faced with the urgent need for investments, in relation to public expectations, all 61 municipalities will increase the pressure on government, aiming at increasing the intergovernmental transfers, taxes and in the same time, borrowing from commercial banks. As previously mentioned, the intergovernmental transfer is not expected to get any significant increase, under the conditions of weak economic growth and high public debt; practically it has been declining since 
2010. On the other hand, the central government wants to avoid any raise of local taxes by municipalities and the new law on local government is expected to maintain restrictions on fiscal autonomy. Meanwhile, the municipalities are aware that there are still rooms for the taxable base, due to a high informality, but this does not mean a level of economic activity capable to yield more taxes. So, notwithstanding the motivation of local government to obtain grants instead of borrowing, the latter seems to be alternative that has the most potential for expansion. In this regard, it is up to the government to review the degree of control on local borrowing, although it is aware that, administrative orders to limit the authority of the borrower for purposes of maintaining levels of public debt have practically impaired, even further, the financial capability of local government. Moreover, the ratio of local government debt to total public debt does not exceed $0.020 \%$, which is a strong argument in favor of local borrowing. The interaction between these three factors: loan limit, size of the grant, and local taxes, will comprise a complex negotiation between the government and municipalities, not to mention the fact that these negotiations will be conducted on an individual basis for each municipality.

In the frame of lending contraction to individuals and businesses during recent years, banks should see local borrowing as a gateway for utilizing excess funds. Municipalities are welcomed clients for banks, due to the perceived low risk, because local borrowing is considered somewhat as bearing a sovereign guarantee. Despite the "legal guarantee" of non-bankruptcy, banks carry out risk analysis for them, as they do it for each customer, but in case of municipalities they always hope in obtaining an additional guarantee, compared to other customers. An important advantage of large municipalities is the improvement of loan applications, based upon studies of profitability, due to an increasing number of high skilled specialists employed by them. In the same time, the improved budget and investment plans will help municipalities to see debt and borrowing as an instrument to improve their position, and not as an embarrassing evidence of their financial vulnerability. Consequently, this fact will be accompanied by a greater number of loan applications, which will pass banks' risk analyses.

The expansion of local borrowing will also lead to improving the role of banks in the territory's economic development, by way of financing investments related to public services, urban and rural infrastructure, and even agricultural infrastructure, which is a prerequisite for the development of agriculture. Bank lending for investment to improve the network of irrigation and drainage systems, reservoirs or other similar works, agriculture markets, collection centers, slaughterhouses, etc., constitute important tools for improving the agricultural business environment. If the government guarantee fund for loans to businesses engaged in investment in agriculture could be extended to include the aforementioned investments by municipalities, it would turn into an important stimulus in this regard. In the long term, the eventual competition between banks will lead to the development of debt instruments, specially designed for municipalities and local government.

\section{Conclusion and Recommendations}

One of the main challenges for the current local government in Albania is to fulfill the growing expectations of citizens for better services and governance. Whereas the functions and responsibilities of local government units have increased during the last decade, the fiscal decentralization and funds transfer have not progressed at the same pace, thus resulting in considerable lack of financing in local infrastructure.

Under a situation of "competition" for budget funds and modest capacity to generate local revenues, the local government units continue to face considerable lack of resources for investment, especially for those requiring big capital such as the road infrastructure and water supply/sewerage infrastructure. Their budgets are generally low and unable to cover funding for large infrastructure improvement projects. Although state budget funds for investments in infrastructure (mainly competitive grants/Regional Development Fund) have been growing over the recent years, their impact is still modest compared with the needs. Coercive fiscal policies that started to be implemented by the Ministry of Finance during the recent years in order to handle the financial crisis also imply that no significant growth is to be expected for several years to come. Moreover, legal initiatives undertaken in 2009 (adjusted as of 2014) regarding the restriction of fiscal autonomy as well as the restriction of the borrowing authority in order to retain the public debt levels, have breached the financial potential of local government units even more.

Notwithstanding the need for improvement and approximation with the European Union legislation, the current legal framework provides adequate regulation for the creation of a local government borrowing system and improvement of the efficiency in using such borrowings for the development of the local infrastructure and services. Therefore, the reform initiated with the reshape of territorial and administrative division should continue with the financial discipline and efficient administration of taxes, collected by local government, aiming at increasing the creditworthiness of local government units in the eyes of lenders, and to benefit maximally from the opportunities provided by legal framework, on 
borrowing options and their efficient use.

In the frame of lending contraction to individuals and businesses during recent years, banks should see local borrowing as a getaway for utilizing excess funds. Municipalities are welcomed clients for banks, due to the perceived low risk, because local borrowing is considered somewhat as bearing a sovereign guarantee.

\section{References}

Local Government borrowing manual, Ornela Shapo (Këmbora), USAID (April 2009).

Templates and procedures for successful Local Government borrowing. Working document for Local Government technical staff. Ornela Shapo (Këmbora), USAID, (March 2011).

Overview of Local Government in Albania for borrowing purposes. Financial data on USAID Local Governance program in Albanian's ten target municipalities. USAID, Ornela Shapo (Këmbora), (May 2008).

Bankieri magazine (page; 7, 9, 12); Local Borrowing, Publication of the Albanian Association of Banks, (No.17, October 2015).

General report to the committee on administrative and territorial reform, "Analysis to the Local Government situation in Albania", (April 2014).

Nezir Haldeda, Fran Brahimi and Elvina Merkaj; "Local Government borrowing issues in Central and Eastern Europe, the case of Albania", EuroEconomica, ISSN: 1582-8859, (Issue 1(32)/2013).

Republic of Albania; Law "On organization and Functioning of the Local Governments" (no. 8652, on 31.07.2000).

Republic of Albania; Law "On bonds of joint stock companies and local government", (no. 10158, on 15.10.2009).

Republic of Albania; Law "On the borrowing of the local government", (no.9869, on 04.02.2008).

Republic of Albania; Law "On the budget management system in the Republic of Albania" (no.9936 on 26.6.2008).

journals.univ-danubius.ro

www2. deloitte.com

www.lgpa.al

www.comt.ca 